\title{
DIVISION OF COMPETENCES BETWEEN THE EUROPEAN UNION AND THE MEMBER STATE
}

\author{
Antun Marinac, MS, PhD Candidate \\ Polytechnic of Požega \\ Vukovarska 17, Požega, Croatia \\ amarinac@vup.hr
}

\author{
Mirela Mezak Matijević, PhD, Assistant Professor \\ Polytechnic of Požega \\ Vukovarska 17, Požega, Croatia \\ mmezakmatijevic@vup.hr
}

\section{Jasmina Mlađenović, LLM, Lecturer}

Polytechnic of Požega

Vukovarska 17, Požega, Croatia

jmladenovic@vup.hr

\begin{abstract}
Starting from the very name of the Scientific Conference "The European Union and the Member States - Legal and Economic Issues", the authors consider that the legislative division of competences between the European Union and the Member States is a key issue for their actions and their mutual relations. Therefore, the aim of the work is to establish a vertical distribution of powers in the European Union and to analyse comparatively the constitutional division of competences between different territorial levels of government in selected European states with federal regulation. The vertical division of competences within the Union is a question of constitutional importance as one of the principles of the structure of authority within its territory. The importance of a vertical division of competences is reflected in particular in the fact that it involves the adoption of very complex decisions on whether a matter should be regulated at a central (European) or at national (state) level. It is important to point out that the process of transferring competence from the higher level (European Union) to the lower forms of territorial organization (Member States) presupposes the instrument and the premise of democratization. At the same time, the range of competences is a form of limitation of the powers of the European Union, within the limits of the competences assigned to it by a primary act. The division of the jurisdiction, apart from legal regulation, has an economic effect. The better the division is, the more effective are the Union and the member states in providing faster and
\end{abstract}


better public services to citizens, without spending much of the state resources, leading to better balance and the prevention of abuse of power.

Work is divided into several interrelated chapters. After the introduction, it is primarily concerned with clarifying general questions about the vertical division of competences between different territorial levels of government. Within this chapter, it starts from the consideration of conceptual definitions, through the analysis of the way of determining competence between territorial levels of authority, the competence to allocate affairs between territorial levels of authority to the vertical division of jurisdiction as a constraint of power.

The central part of the paper deals with the analysis of the delimitation of competences between the European Union and the Member States as defined in the Lisbon Treaty, which includes: a) exclusive competence of the European Union, b) shared competences between the European Union and the Member States and c) competence to support, coordinate and complement Member States' actions. Particular emphasis is placed on the following principles: the conferred powers and subsidiarity and proportionality. They are based on the implementation of competences between the Union and the Member States. These principles represent the basic principles for the functioning of the European Union and the creation of its law. Within this framework, the exclusive competence of the Member States, the functioning of the Union outside its established jurisdictions, the principle of genuine co-operation between the European Union and the Member States, as well as the obligation to apply European Union legislation adopted in the area of jurisdiction are considered.

Particularly, it deals with the issue of control of the principles of authority, subsidiarity and proportionality before the Court of Justice of the European Union.

The method of comparative analysis analyses the constitutionally defined vertical division of competences in the selected European federal states: the Federal Republic of Germany and Switzerland. On the basis of a comparative method, it is possible to conclude that there are similarities between vertical delimitation within the European Union and vertical distribution of jurisdiction in federal states.

In addition to comparative method, regarding research methodology, the paper uses secondary research and normative and historical method.

Keywords: Member States, European Union, Lisbon Treaty, principle of conferred powers, vertical division of competences.

\section{INTRODUCTION}

Historically, the distribution of competences between the EU and the Member States in the period prior to the Lisbon Treaty was not regulated by earlier founding treaties. In this connection, the European Commission has warned in the White Paper on European Governance in 2001 on the problems of a clear delimitation of competences between the European Union and the Member States, stressing that "the Union needs clear principles that identify how competence is shared between the Union and its Member States. In the first place this is to re- 
spond to the public's frequent question "who does what in Europe?". ${ }^{1}$ Only after the entry into force of the Lisbon Treaty the distribution of powers in the EU was clearly regulated. Namely, the uniqueness of the EU as a special kind of genus (sui generis) is manifested through competence, i.e. a part of the sovereignty that the states convey to it.

Some authors argue that the EU is shaped by the experiences of federal states ${ }^{2}$. According to Robert Schütze, the European Community is implicitly based on the German idea of executive federalism, whereby the Community prescribes European law, and the Member States enforce this law ${ }^{3}$. Thus, a comparative representation of the division of competencies in the selected European countries is logical (Federal Republic of Germany and Switzerland).

This paper is based on the underlying hypothesis that there are similarities of vertical delimitation between the European Union and compared states (the Federal Republic of Germany and Switzerland).

\section{GENERALLY ON VERTICAL DIVISION OF COMPETENCES BETWEEN DIFFERENT TERRITORIAL LEVELS OF GOVERNANCE}

Apart from the horizontal division of governance (division in the centre), there is a vertical division (applies to different territorial levels of government). Zvonimir Lauc, under the vertical division of governance, implies vertical relations between higher / wider and lower / narrower territorial units (from local, across regional, national and supranational levels). ${ }^{4}$ The aforementioned author considers that competence is not an affair, but a right to decide on certain policies, i.e. competence and responsibility. ${ }^{5}$ Vertical division of governance, with the establishment of the basic relations between the territorial levels of governance, primarily encompasses the determination of competences of different levels of government.

1 White Paper on European Governance, Commission of the European Communities, COM (2001) 428, Brussels, 25.7.2001, p. 24

2 Lehmann. W., Attribution of Powers and Dispute Resolution in Selected Federal Systems, Working Paper, European Parliament, 2002, p. 1

3 Schütze, R., From Rome to Lisbon : Executive federalism' in the (new) European Union, Common market law review., Vol. 47, No. 5, 2010, p. 1424

4 Lauc, Z., Temeljni pojmovi lokalne samouprave, Lokalna samouprava: hrvatska i nizozemska iskustva, Hrvatski institut za lokalnu samoupravu Osijek i Interkerklijk Vredesberad Haag, Osijek, 2001, p. 32

$5 \quad$ Lauc Z., Odgovornost lokalne demokracije, u Ustavna demokracija i odgovornost, Okrugli stol održan 22. studenoga 2012. u palači Akademije u Zagrebu, Knjiga 19, Hrvatska akademija znanosti i umjetnosti , Znanstveno vijeće za državnu upravu, pravosuđe i vladavinu prava, Zagreb, 2013, p. 104 
In that context, scholars began to elaborate theories of multilevel governance. Not only have they suggested explaining European integration as the outcome of joint decisions of national and European actors, they also have revealed that decisions on the vertical allocation of competences usually result in an interlocking of European, national and sub-national levels. Consequently, the transfer of powers to the EU should no longer be considered as a zero-sum game, rather it is about finding ways to deal with interdependent tasks reaching beyond boundaries of national governments ${ }^{6}$.

Te delimitation of competences between the EU and the Member States under the Lisbon Treaty represents a vertical delimitation of powers between the EU and the Member States, as discussed below.

\section{DISTRIBUTION OF COMPETENCES BETWEEN THE EUROPEAN UNION AND MEMBER STATES, ACCORDING TO THE LISBON AGREEMENT}

The European Union is organized on the federal principle, which in particular implies a constitutionally guaranteed division of sovereignty between the two levels of government. Such division of governance requires making complex decisions about whether a matter will be regulated at European or national level.

The EU is based on the principle of transferred / assigned powers from Member States to the EU. This principle is contained in Article 1 (1) TEU, according to which the Member States establish the EU with each other, to which they delegate competences for achieving common goals. In this way, the Member States have limited their autonomy, transferring, based on the membership, their regulatory powers in certain areas of the EU.

Sacha Garben and Inge Govaere, in their book entitled "The Division of Competences Between the EU and its Member States", emphasize that the delimitation of competencies between the EU and the Member States are of fundamental importance as it reflects the "negotiating power" achieved between the Member States and the Union in terms of determining the limits of EU authority and limiting the authority of Member States. According to them, the issue of delimitation of jurisdiction defines the nature of the EU as a state union, as well as the identity of the Member States ${ }^{7}$.

Benz, A.: Zimmer, C., The EU's competences: The 'vertical' perspective on the multilevel system, Living Reviews in European Governance, Vol. 5, No. 1, 2010., p. 18

Garben, S., Govaere, I., The division of competences between the EU and its member states, Oxford: Hart Publishing, 2017, Modern studies in European law, 2017., p. 1 
According to Branko Smerdel, the distribution of competences between the Member States and the Union is a question of constitutional nature" ${ }^{8}$ Similar argument is given by Arsen Bačić, stating that the allocation of the classical state functions is also current for the constitutional law of the EU, although the EU is not a state but an international organization sui generis. ${ }^{\text {? }}$

The basic legally binding act in force on which the EU is based is the Lisbon Treaty ${ }^{10}$ consisting of the Treaty on European Union (hereinafter referred to as the "TEU") and the Treaty on the Functioning of the European Union (hereinafter: TFEU). Meanwhile, there have been changes to the aforementioned Treaties and currently revised versions of the TEU and the TFEU from 2016 are in force. ${ }^{11}$

Title I of the TFEU is titled "Categories and Areas of Union Competence" within which the distribution of competences between the EU and the Member States has been carried out on:

- exclusive competence of the European Union (Article 3 of the TFEU)

- shared competence between the EU and the Member States (Article 4 of the TFEU)

- competence to support, coordinate and complement Member States' actions (Article 6 of the TFEU)

Apart from the aforementioned competences, the Lisbon Treaty also recognises:

- the competences of the Member States as defined by the general clause and

- the functioning of the Union beyond its established competences.

\subsection{Exclusive competences of European Union}

In the area of exclusive jurisdiction pursuant, only the Union may create and adopt legally binding acts, while Member States may do so independently such is authorized by the Union or for the purpose of implementing Union acts (Article 2 (1) of the TFEU). In the above issues, the EU has acquired the sole right to decide and the states cannot decide on these issues even if the Union has not resolved it. Areas of exclusive jurisdiction, according are: the customs union, the definition

8 Smerdel, B., Ustavno uredenje europske Hrvatske, Official Gazette, Zagreb, 2013, p. 224

9 Bačić; A., Ustavno pravo Republike Hrvatske, Praktikum, Pravni fakultet Sveučilišta u Splitu, 2010, p. 559

10 Treaty of Lisbon amending the Treaty on European Union and the Treaty establishing the European Community, signed at Lisbon, 13 December 2007, Official Journal C 306 of 17 December 2007

11 Consolidated versions of the Treaty on European Union and the Treaty on the Functioning of the European Union, Official Journal of the European Union, C 202, Volume 59, 07.06. 2016 
of the competition rules necessary for the functioning of the internal market, the monetary policy for the Member States whose currency is the euro, the conservation of marine biological resources within the common fisheries policy and the common trade policy (Article 3 (1) of the TFEU).

The very creation of categories of competence inevitably means that there will be problems of demarcating borderlines between the different categories. Such problems can arise in demarcating the line between exclusive and shared competence. There are, for example ambiguities about the relationship between the competition rules which are a species of exclusive competence, and the internal market which is shared competence ${ }^{12}$.

Exclusive competences of the Union are also related to its external competences. In that regard, Hoffmeister emphasizes that Article 2(1) of the TEU expresses the rule that Member States can no longer act in such exclusive Union policies unless if so empowered by the Union. Accordingly, Union law contains a strong indication that in areas of exclusive external Union competence action of either Union institutions or the Member States should be attributed to the Union, as only the Union has the legal power to act in this field and to remedy a potential breach of international law ${ }^{13}$.

\subsection{Shared competences between European Union and Member States}

In the area of shared competence, legally binding acts may be created and adopted by the Union and the Member States. In doing so, the Member States exercise their competence to the extent that the Union does not exercise. In addition, Member States re-enforce their jurisdiction to the extent that the Union has decided to terminate its jurisdiction (Article 2 (2) TFEU). This implies that Member States can only act if the EU decides not to act in a given area. In this case, it is about interdependence between the levels of government, since it is allowed to the EU to adopt certain legal acts, and for those acts to be implemented by member states.

The shared competences between the EU and the Member States include: internal market, social policy for the aspects laid down in the Treaty, economic, social and territorial cohesion, agriculture and fisheries, with the exception of preserving marine biological resources, environmental protection, consumer protection,

12 Craig, P., The Lisbon Treaty Law, Politics and Treaty Reform, Oxford University Press, 2010, p. 159-161

13 Hoffmeister, F., Litigating against the European Union and Its Member States - Who Responds under the ILC'S Draft Articles on International Responsibility of International Organizations?, The European Journal of International Law Vol. 21, No. 3, C EJIL 2010, p 743 
transport, trans-European networks, the area of freedom, security and justice, and common security issues in public health, for the aspects laid down in the Treaty (Article 4 TFEU).

It is in the area of shared competences that most difficulties arise where it can still be unclear whether the Union or the member states have the competence for a particular action. Furthermore, the degree of sharing also alters according to the subject matter: for example in areas such as the internal market, as soon as the Union acts under its competence, it assumes exclusive power to act in conflict. If, however the Union chooses not to acts, the member states retain the power to act $^{14}$.

In the area of shared competence, the EU in relation to the Member States has a primacy in the exercise of competence, but it can do so only with the application of the principle of subsidiarity and proportionality. The legal basis for applying the subsidiarity principle is the first part of Article 5 (3) UEU, according to which, in areas not within the exclusive competence of the EU, the Union acts only if, and in the extent that Member States cannot achieve, the objectives contained in the proposed measures at the central, regional or local level cannot be achieved in a satisfactory manner, which can, due to the scope or the effect of the proposed measure, be better achieved at the Union level.

From the TEU regulation above it can be concluded that Article 5(3) encapsulates a double test for the enforcement of the principle of subsidiarity, allowing the EU to act when it has the power to do so. It is presumed that Member States have priority to take action in the domains of shared competences unless this presumption is rebutted by passing the double test. This double test encompasses, as its first prong, a sufficiency test permitting the EU to act "only if and in so far as the objectives of the proposed action cannot be sufficiently achieved by Member States". As its second prong, there is a value-added test: the EU 's action "by reason of the scale or effects of the proposed action (can) be better achieved at the Union level". Both tests are cumulative, and the sufficiency test is the sine qua non condition to the valueadded test ${ }^{15}$.

Subsidiarity decides, where there are multiple layers of government at which level policy decisions will be made. There is this distinction between question of wheth-

14 Foster, N., Eu Law Directions, Oxford University Press, Oxford, 2016, p 79

15 Portues, A., The principle of subsidiarity as a principle of economic efficiency, Columbia Journal of European Law, Vol. 17, 2012., p. 244 
er EU competence exists and the question of whether the EU should be taken as closely exercise that competence ${ }^{16}$.

In addition to respecting the principle of subsidiarity, the EU must also respect the principle of proportionality, according to which the content and form of measures taken by the Union must not go beyond what is necessary to achieve the objectives of the Treaty (Article 5 (4) TFEU).

Traditionally, federally structured systems of shared regulatory powers presume a set of conflicting rules. Therefore, potential conflicts between multiple levels of management are possible. In this respect, the EU system is not an exception ${ }^{17}$.

\subsection{Competence to support, coordinate and complement Member States' actions}

In within these competences, "the Union shall have competence to carry out actions to support, coordinate or supplement the actions of the Member States, without thereby superseding their competence in these areas" (Article 2 (5) TFEU). Regulatory relations remain within the competence of the Member States under these competences.

Areas covered by the competence to support, coordinate and complement Member States' actions are: protection and improvement of human health, industry, culture, tourism, education, vocational training, youth and sport, civil protection and administrative cooperation.

The creation of categories of competence inevitably means that there will be boundary problems as between them. Thus for example, regulation of the media might come under the internal market which is shared competence, or it might be regarded as falling within culture, where only supporting, etc action is allowed. There are moreover difficulties in deciding which aspects of social policy fall within shared competence, and which come within this category ${ }^{18}$.

\subsection{Competences of Member States as set out in general clause}

The competences that the Treaties have not given to the Union shall be retained by the Member States (Article 5, paragraph 2, second sentence of the TEU). It is ap-

\footnotetext{
16 Steiner, J., Woods, L., EU Law, 11th edn Oxford University Press, Oxford, 2012, p. 56-57

17 Van Cleynenbreugel, P., Sharing powers within exclusive competences: Rethinking EU Antitrust Law Enforcement, CYELP, Vol. 12, 2016, pp. 49-79, p. 69

18 Craig, P., De Búrca G., EU Law, Oxford University Press, Oxford, 2011., p. 86
} 
parent from this contractual provision that the competences of the Member States are defined by the general clause, since they are all affairs that do not explicitly belong to the EU.

For example, in the EU, responsibilities for redistribution and stabilization measures largely lie with Member States because there is no true EU policy to combat unemployment. At the same time, some Member States are not able to provide incentives to the economy by reducing interest rates, since this responsibility has been transferred to the European level (European Central Bank). Member States are trying to, in certain extent, coordinate macroeconomic policies, but this coordination still does not meet the usual coordination of macroeconomic policies at central government level within the existing federations, such as is the case in the Federal Republic of Germany and Switzerland ${ }^{19}$.

\subsection{Union's operations outside its established competences}

If, within the framework of the policies laid down in the Treaties, the Union is required to achieve one of the objectives set out in the Treaties, and the Treaties do not provide the necessary powers, the Council, acting unanimously on a proposal from the Commission and with the prior consent of the European Parliament, shall adopt appropriate measures (Article 352 (1) TFEU).

The Court of Justice of the European Union has made clear that Article 352 TFEU, „being an integral part of an institutional system based on the principle of conferred powers, cannot serve as a basis for widening the scope of (Union) powers beyond the general framework created by the provisions of the Treaty as a whole and, in particular, by those that define the tasks and the activities of the (Union). These article cannot be used as a basis for the adoption of provisions whose effect would, in substance, be to amend the Treaty without following the procedure which it provides for that purpose ${ }^{\text {"20 }}$. This case law is recalled in declaration number 42 to the Treaties ${ }^{21}$. The Court of Justice of the European Union has contributed to the respect of the principle of delegated powers, in the broader contractual terms (Article 352 TFEU), stating that provision of Article 352 of the TFEU cannot serve as a basis for spreading the Union's competences through the Treaty as a whole.

19 Börzel, T. A.; Hosli, M. O., Brussels between Bern and Berlin: Comparative Federalism Meets the European Union, Governance, Vol. 16, No. 2, 2203, pp. 179-202, 188

20 The role of the „Flexibility clause“: Article 352, [https://ec.europa.eu/commission/sites/beta-political/ files/role-flexibility-clause_en.pdf] Accessed 03.05.2019

21 Declaration on Article 352 of the Treaty on the Functioning of the European Union, Official Journal of the European Union, C 202, Volume 59, 07.06. 2016 


\subsection{Obligation to apply European Union regulations adopted in area of competence distribution}

For European legislation, which is adopted within the division of competences between the EU and the Member States, it is characteristic that it is binding in its entirety and is applicable directly in all Member States.

Craig i De Búrca emphasize that the doctrine direct effect applies in principle to all binding EU law including the Treaties, secondary legislation, and international agreements. Thereby, the aforementioned authors warn that the most problematic issues concern directives and international agreements ${ }^{22}$. Tamara Ćapeta and Siniša Rodin write that the EU legislation has a direct effect in the Member States, and is applied by national courts, i.e. in out-of-court situations, national public administration ${ }^{23}$. Direct effect, in legal order of the EU emanates from generally accepted practice of the Court of Justice of the European Union, which started with its judgment in Van Gend end Loos case from 1963. In the aforementioned judgment, it was concluded that the Article 12 of the Treaty establishing the European Economic Community creates direct effects and gives legal entities subjective rights that national courts are obliged to protect. ${ }^{24}$

In general, the relationship between the EU and the Member States, in accordance with Article 4 (2) of the TEU, "the Union respects the equality of Member States before the Treaties and their national identity which is inextricably linked to their fundamental structures, political and constitutional, including regional and local self-government. The Union respects the fundamental powers of the state, including ensuring territorial integrity of the state, maintaining law and order, and preserving national security. In particular, national security remains the exclusive competence of each Member State."

\section{CONTROL OF PRINCIPLES OF ASSIGNED COMPETENCES, SUBSIDIARITY AND PROPORTIONALITY BEFORE THE COURT OF JUSTICE OF THE EUROPEAN UNION}

The Court of Justice of the European Union has a strong influence on the legislative activity of the Union which can be attributed to the fact that the European legal system, in particular at its inception, was incomplete and unscru-

\footnotetext{
22 Craig,; De Búrca, op.cit., note 18, p. 180

23 Ćapeta, T.; Rodin, S., Osnove prava EU, II. izmijenjeno i dopunjeno izdanje, Narodne novine d.d., Zagreb, 2011, str. 29

24 Case 26/62 NV Algemene Transport- en Expeditie Onderneming van Gend \& Loos vNetherlands Inland Revenue Administration, ECR(English special edition) 1
} 
pulous and lacked precise criteria for the division of competences between the then Community and the Member States. ${ }^{25}$ The answer to the question of vertical distribution of competences in the EU, according to Tamara Ćapeti, is extremely politically important and sensitive issue for the Court of Justice of the European Union. ${ }^{26}$ Namely, disputes involving the validity of the EU act, if the EU regulates a matter outside its jurisdiction, is a new phenomenon at the EU level.

Proceedings against acts of European political institutions have been initiated before the Court of Justice of the European Union on the grounds of transgressions of competences. ${ }^{27}$ In this connection, Trevor Hartley notes that it is rare that the Court of Justice of the European Union will rule the nullity of the measure due to lack of competence. On the contrary, the usual basis for its adoption in the wrong process or on the wrong legal basis or the violation of a higher legal rule ${ }^{28}$. Famous is the case of Tabacco Products ${ }^{29}$, in which Germany initiated proceedings before the Court of Justice of the European Union for the annulment of a directive imposing a general prohibition on the advertising or sponsorship of tobacco products in the EU. In that case, the Court upheld an interpretation allowing the Community to adopt measures on the labelling of tobacco products with the alleged purpose of functioning of the common market, the by-product of which was a disturbance of trade patterns, which could reasonably be suspected that the true purpose of the measure was not the functioning of the market but the health protection (but its harmonization by the Community is prohibited by the Treaty)..$^{30}$ Namely, since the Union is bound by the principle of assigned competences, it has no exclusive competence to legislate in the area of public health but can adopt incentive measures.

However over the next few years the concept was refined and developed so that exclusive and non-exclusive implied powers emerge. We have already seen that in Kramer the Court found that the Community may possess implied powers even where there hat not been any prior development of common rules ${ }^{31}$. However -

25 Rodin, M., Temeljna načela koja određuju odnos prava Europske unije i prava država članica, Hrvatska pravna revija, 2012, pp. 1-14, 5

26 Ćapeta, T., Sudska zaštita u Europskoj uniji nakon Lisabonskog ugovora, in: Reforma Europske Unije-Lisabonski ugovor, Official Gazette, Zagreb, 2009, p. 101

27 Perišin, T., Razgraničenje ovlasti Europske unije i država članica, in: Reforma Europske Unije-Lisabonski ugovor, Official Gazette, Zagreb, 2009, p. 219

28 Hartley, T., Temelji prava Europske zajednice: uvod u ustavno i upravno pravo Europske zajednice, 2. hrv. izd. Rijeka, Pravni fakultet Sveučilišta, 2004, p. 118

29 Case C-376/98 Germany v Parliament and Council (Tobacco Advertising I) [2000]

30 Perišin, T., Ima li Europska unija ovlast regulirati privatno (posebice ugovorno) pravo?, Zbornik Pravnog fakulteta Zagreb, Vol. 62, No. 5-6, 2012, p. 1799-1822

31 Cases 3, 4, and 6/76 Kramer (n 11 above) [30]-[33] 
in order to avoid a legislative vacuum-the Court recognized the continued (concurrent) existence of Member States competence for as long as the Community competence had not yet been exercised. Exclusive Community competence was not compatible with the mere potential for Community action. This concurrent competence was transitional only and subject to the overall obligation to comply with Community rules found what was then Article 5 off the EEC Treaty (now Article 4(3) TEU) and a more specific obligation coordinate their actions then found in Article $116 \mathrm{EEC}^{32}$.

The caseload of the Court of Justice of the European Union depends primarily on factors that are external to the Court, such as the increasing size of the EU after the enlargements, the gradual but constant extension of EU competences into new policies areas, the increased salience of EU action, the growing constellation of economic, political and social interests involved in the enforcement of EU law, the more or less collaborative attitude of the national courts, the Commission's willingness to pursue infringement proceedings against Member States, the general phenomenon of "judicialisation" (the tendency to a greater presence of judicial institutions in political and social life), and so on. Internal factors, such as whether the Court takes a liberal or strict attitude to the admissibility of the action, are not the most important elements affecting the caseload ${ }^{33}$.

Trevor Hartley also points out that the Court of Justice of the European Union has not yet abolished the regulation based on subsidiarity. ${ }^{34}$

Certain national constitutional courts also question whether the EU complies with the agreed order of competency. In connection with this, Jasna Omejec, cites an example of the German Federal Constitutional Court in controlling the delimitation of competences between the Member States and the EU in each individual case. In these cases, the Federal Constitutional Court is examining whether legal instruments of European institutions remain under the principle of subsidiarity within the limits of the sovereign rights conferred on them by virtue of delegated competences. ${ }^{35}$ An example of this is the verdict of the German federal court BVerfGE 123, 267. ${ }^{36}$ In this decision, the Federal Constitutional Court ruled that the

32 Craig, P.; De Búrca, G., The evolution of EU law, Oxford, Oxford University Press, 2nd edition 2011, p. 245

33 Itzcovich, G., The European Court of Justice as a Constitutional Court. Legal Reasoning in a Comparative Perspective, SANT'ANNA LEGAL STUDIES, STALS RESEARCH PAPER Vol. 4, 2014, p. 12

34 Hartley, op. cit., note 28, p. 117

35 Omejec, J., Veliki njemački ustav i nepromjenjiva ustavna načela u praksi Saveznog ustavnog suda, 2016., [https://bib.irb.hr/datoteka/792156.OMEJEC_-_GRUNDGESETZ__Zbornik_PRAVO_I_PRAVDA_2015_PFBgd.pdf] Accessed 03.03.2019

36 BVerfGE 123, 267-Lisbon Decision (Lissabon-Urteil) 
Treaty of Lisbon Ratification Act was compatible with the German Federal Constitution. In the aforementioned Decision, an increasing number of competences are highlighted and further subdivisions of the bodies of the European Union. In this respect, the Court considers it necessary to preserve the fundamental principle of limited individual powers subject to the control of the Member States. The Decision also warned that the constitutional identity was established by the Federal Constitution (Article 23, paragraph 1 al.3, Article. 79, paragraph 3) as the inalienable element of democratic self-determination of peoples. It is therefore necessary that the Federal Constitutional Court within its competence watches that the EU, with its modern acts, does not breach competences given to it.

One of the jurisdiction of the Court of Justice of the European Union represents the settlement of disputes between national governments and EU institutions (Article 19 of the TEU). Therefore, the most common procedures before the Court of Justice of the European Union include direct action against the Member States (Article 258 of the TFEU) and direct suits against EU institutions (Article 263 of the TFEU).

The Republic of Poland filed a lawsuit against the European Parliament and the Council of the European Union in Case C-358/14. A series of various provisions adopted at the Union level on the production, presentation and sale of tobacco and related products on the European internal market is also presented by the Directive 2014/40 / EU based on which the Union legislature forbade the sale of menthol cigarettes on the European internal market. Therefore, on 22 July 2014, the Republic of Poland filed a lawsuit against the European Parliament and the Council of the European Union for annulment of the said Directive. In that lawsuit, the Republic of Poland has also violated the principle of subsidiarity, given the local character, which is limited to the narrow group of Member States. Poland considers that this issue should be addressed at the national level only in those Member States where there is a high level of consumption and production of these products. The Court has, with its Judgment of the Court (Second Chamber) of 4 May 2016, dismissed that complaint ${ }^{37}$.

In its judgment of 6 September 2017, the Court of Justice of the European Union (Grand Chamber) dismissed the action brought by the Republic of Slovakia (Case C-643/15) and Hungary (Case C-647/15) against the Council of the European Union. Slovakia and Hungary have sought annulment of Council Decision (EU) $2015 / 1601$ of 22 September 2015 on the introduction of provisional measures in the field of international protection in favour of Italy and Greece (SL 2015,

37 Case C-358/14 Republic of Poland v. European Parliament, Council of the European Union [2016] 
L 248, p.80). The grounds for the prosecution were based on the inadmissibility of Article 78, paragraph 3 of the TFEU as the legal basis for making the decision challenged. The Court's assessment of Article 78 paragraph 3 of the TFEU allows only "provisional measures" (point 89) to be adopted, so it is a crisis management measure adopted at the Union level, whose purpose is to guarantee real realization, respecting the Geneva Convention, the fundamental right to asylum (paragraph $343)^{38}$.

In Case C-288/12, the European Commission filed a lawsuit before the Court of Justice of the European Union of Justice against Hungary for breach of the obligation of the Member State. Hungary sued for the infringement of Directive 95/46 / EC of the European Parliament and of the Council of 24 October 1995 on the protection of individuals with regard to the processing of personal data and on the free flow of such data. It is the obligation of the Member States to provide that the application of the provisions adopted pursuant to the directives is supervised by one or more public bodies which, in the performance of the functions entrusted to them, operate completely independently. This refers to the alignment of a national regulation that finishes the six-year mandate of a data protection trustee, including the establishment of a national data protection and information freedom authority, and a nine-year mandate for persons other than the Data Protection Commissioner for the presidency of said body. In its judgment of 8 April 2014, the Court ruled that Hungary had infringed its obligations under the aforementioned provisions of Directive 95/46 / EC of the European Parliament and of the Council of 24 October 1995 on the protection of individuals with regard to the processing of personal data and on the free movement of persons and the flow of such data, ending the mandate of an independent supervisory body for the protection of personal data ${ }^{39}$.

In that context, respect for the principles of assigned competences, subsidiarity and proportionality is subject to the control of the Court of Justice of the European Union. Regulating jurisdiction at different levels (competences are granted legally, not politically) is a cause for conflict of jurisdiction.

An example of the Court of Justice of the European Union is approach to subsidiarity is the judgment in Case C-233/94, Germany v. the European Parliament and the Council, in which the Court accepted implicitly and rather limited justification as sufficient to justify compliance with the principle of subsidiarity. The Court concluded that the Union could act, if the objective cannot be achieved by

\footnotetext{
38 Case C-643/15 and Case C-647/15 Slovak Republic and Hungary v Council of the European Union [2017]

39 Case C-288/12 European Commission v Hungary [2014]
} 
the Member States ${ }^{40}$. In the second judgment, of a newer date, the Court of Justice of the European Union has clarified that respecting the obligation to state reasons in respect of the principle of subsidiarity must be judged not only with regard to the wording in the contested act, but also given its context and circumstances in the individual case. In this case, the Court specifically examined whether the Commission's proposal and the assessment of the effects of sufficient information that clearly and unequivocally demonstrate the benefits of Union action at the level of Member States ${ }^{41}$.

\section{COMPARATIVE OVERVIEW OF CONSTITUTIONAL DIVISION OF GOVERNANCE IN SELECTED EUROPEAN COUNTRIES}

In the debate on the future European order, the EU was often described as an "emerging federation". The EU is comparable to the Federal Republic of Germany and Switzerland because all three are organized on a federal basis and are constitutionally guaranteed the division of sovereignty between the levels of government. For example, Tanja A. Börzel and Madeleine O. Hosli, relying in particular on the examples of Germany and Switzerland, stressed that greater delegation of authority to the central EU level must be in parallel with strengthened forms of fiscal federalism and enhanced representation of functional interests at the European level. In their view, without such "rebalance", the problems of EU legitimacy would probably be intensified ${ }^{42}$.

Among the typology of the form of division of governance, Arsen Bačić, also mentions federal or vertical division of governance. ${ }^{43}$ The same author reminds that federalism represents the territorial dimension of a particular political system and the organizational principle for the territorial distribution of governance". ${ }^{44}$ The Federal State is a complex state comprising of several states, each of which is a special state with a special state governance. Unlike the unitary state, where power is administered in a unique way, the federative state represents one of the vertical forms of governmental organization, the constitutionally guaranteed division of state power between the federative state and the federal states. The federal states and federal units are political communities that are independent of each other and where there is a partnership relationship. In the federal states, there

\footnotetext{
40 Case C-233/94 Germany v Parliament and Council [1997] ECR I-2405

41 Case C-547/14 Philip Morris, EU C: 2016: 325

42 Börzel; Hosli, op. cit., note 19, p. 179

43 Bačić, op.cit., note 9, p. 114

44 Bačić, A., Politička gramatika federalizma i hrvatsko povijesno iskustvo, Zbornik radova Pravnog fakulteta u Splitu, Vol. 44, No. 2, 2007, p. 166
} 
is a division of sovereignty. This means that there is no hierarchy between the levels of governance in the federal model, and the communities that form it are not in the mutual relationship of supremacy and subordination, but some of them are narrower while others are wider.

German political scientist Franz Neumann argues that federalism is one of the ways of preventing abuse of power by dividing power between a number of competing power-holders ${ }^{45}$. Why is that so? Federalism allows something that Montesquieu has recognized as the goal: limiting the power of the state. According to Montesquieu, power can only be overwhelmed by power, an attitude that will rarely be disputed. Thus, the power of the central government is opposed by the power of federal units.

The consequence of the federal principle is the division of state affairs, within each of the functions. That is why federal scope differs from the scope of units. It is precisely this division of competence, especially legislative power, that is one of the essential features of federalism. ${ }^{46}$ According to Arsen Bačić, the goal of the federal constitution is the institutionalization of the balance between state unity and subnational differences. ${ }^{47}$ One of the fundamental constitutional features of the federal state according to Branko Smerdel is the federal constitution regulating the division of competences between the federal state and the member states ${ }^{48}$ which also points out that the organizational principle of federalism is the noncentralization where diffusion and division of power between many centres is constitutionally implemented and guaranteed ${ }^{49}$

\subsection{Vertical division of competences in the Federal Republic of Germany}

German Federal Constitution (the Basic Act of the Federal Republic of Germany) ${ }^{50}$ guarantees federalism as a form of association of political communities that determines:

- creation of the Federal Republic of Germany expressly as a federal state (Article $20(1)$,

\footnotetext{
45 Neumann F., Demokratska i autoritarna država. Zagreb, Naprijed, 1974, str.181

46 Vrban, D., Država i pravo, Golden marketing, Zagreb, 2003, p.120

47 Bačić, A., Ustavno pravo i političke institucije, Pravni fakultet u Splitu, 2012, p.139

48 Smerdel, B., op.cit., note 8, p. 201

49 Smerdel, B. (ed.), Primjena federalnog načela i pouke ustavne reforme 1971., Pravni fakultet Sveučilišta u Zagrebu i Centar za demokraciju i pravo Miko Tripalo, Zagreb, 2007, p. 30

50 Grundgesetz für die Bundesrepublik Deutschland, 23.05.1949
} 
- the division of the German territory into countries as the basis for their right to participate in the legislation and principles of Article 1 (these principles are: human dignity, inviolability and inalienability of human rights as the foundation of every community, peace and justice, and the division of power into: legislative, executive and judicial) and the abovementioned Article 20 (Article 79 (3)),

- multiple levels of territorial governance.

In addition to the two state levels: a) federal state and (b) provincial level, there are c) districts in the Federal Republic of Germany and d) municipalities. Relationships between the federal state and the countries regulated in part II of the Federal Constitution (Articles 20 to 37). The Federation and the federal states enjoy sovereignty. This dual state is still reflected in the fact that the federal states also have their own competences in legislation, administration and judicature.

Article 30 of the Federal Constitution is a fundamental norm for the division of competences between the Federation and the states, prescribing that the states are responsible for the implementation of state authorizations and execution of state affairs, unless otherwise stipulated by the Federal Constitution. In this case, the affairs of the states are defined by the general clause, because they are all affairs that are not explicitly prescribed to belong to the federal state. The remaining competences have been transferred to states that have their state functions. Each state has its own state constitution and an autonomous internal political structure, and hence independent political institutions of legislative, executive and judicial authority.

Regarding the relationship between the federal state and the states, it should be noted that the Federal Constitution stipulates:

- the primacy of the Federal Constitution over State acts (Article 31), which means that the federal law overrides state law,

- the constitutional position of states must be in accordance with the principles of the federal state (Article 28 (1),

- states have the power to legislate, unless the Federal Constitution placed legislative powers in the competence of the Federation (Article 70 (1)), and

- the competences of the Federation and the states are divided by the provisions of the Federal Constitution, on exclusive and competing legislative powers (Article $70(2))$.

The Federal State can perform only those affairs that are explicitly defined in the Basic Act as federal governmental affairs. The exclusive powers (legislative power) 
of the Federal State are defined in Article 73 of the Constitution, which includes 14 areas: 1) external affairs and defences, including the protection of civilians; 2) federal citizenship; 3) freedom of movement, issuance of passports, immigration and emigration, extradition; 4) monetary policy, money laundering, units of measurement and timing; 5) unity of the customs and trade area, merchant and maritime contracts, free movement of goods and foreign and international goods and customs, customs protection and border protection; 6) federal railways and air traffic; 7) post office and telecommunications; 8) legal relations of persons employed in federal and public legal bodies directly dependent on the Federation; 9) protection of industrial property rights, copyright and publishing rights; 10) Federation and state cooperation; a) in the area of criminal police, b) to protect the foundations of free democratic organization, stability and security of the Federation or states, c) to defend against attempts to threaten the interests of Germany abroad trough force or prepared violence in the federal territory, and to establish Federal Criminalistics offices and international fight against crime; 11) collecting statistical data for federal purposes; 12) explosives legislation; 13) the issue of war invalids and war victims and care for former prisoners of war; 14) the production and use of nuclear energy for peaceful purposes, the construction and operation of facilities serving for such purposes, protection against the dangers arising from the release of nuclear energy or ionizing radiation and the disposal of radioactive substances.

Pursuant to Article 30 of the Federal Constitution, the states have exclusive jurisdiction in all matters not attributed to the Federation by the Constitution. The constitutions of states have determined which state level is competent for which function. Accordingly, federal states carry out a large number of public affairs in the field of police, education (primary and secondary), law enforcement, radio and television broadcasting, culture and communal affairs. Higher education is also under the jurisdiction of the federal states and is dominated by public faculties, with just a few private ones.

Article 83 of the Federal Constitution determines that the application of federal laws is the competence of the states, unless the Federal Constitution states otherwise. In this regard, if the federal law application is the competence of the states, they themselves regulate the organization of the government and the administrative procedure, unless the federal law, adopted with the consent of the Federal Council, provides otherwise (Article 84 (1)).

Article 72 of the Basic Act regulates competing legislation between the Federation and the states, as follows: 
1) in the area of competing legislative powers of the Federation, the states have the power to legislate for so long and to the extent that the Federation has not exercised its legislative competence (Article 72 (1));

2) in the areas referred to in Article 74, paragraph 1, points 4, 7, 11, 13, 15, 19a, 20, 22, 25 and 26 of the Federal Constitution ${ }^{51}$, the Federation has the right to legislate until such time as equal living conditions are established throughout the federal territory, or in order to maintain legal or economic unity of the national interest (Article $72(2)$ );

3) If the Federation has used its legal powers, the states may legislate in the field of hunting, nature conservation and landscape management, land allocation, spatial / regional planning, water regulation and higher education (Article 72 (3));

4) a federal act may prescribe that federal regulations which are no longer needed, within the meaning of paragraph 2, may be replaced by a national act (Article 72 (4)).

Article 74 defines 33 areas of competing legislative authority of the Federation: 1) civil law, criminal law and execution of penalties, organization of courts, court proceedings, attorney's office, notary office and legal advisory service; 2) personal data; 3) the right of association and assembly; 4) the right of aliens to stay and settle; 5) repealed; 6) refugees and displaced persons; 7) public care (without maintenance); 8) repealed; 9) war damages and repairs; 10) care for war veterans, war widows and orphans and former prisoners of war, tombs of soldiers and other victims of war and terror; 11) economic law (mining, industry, energy, crafts, small business, trade, banking and securities market, private-law insurance institutes); 12) labour law, including organization of enterprises, labour and employment protection and social security, including unemployment insurance; 13) establishing support for education and enhancement of scientific research; 14) the right to expropriation, if it does not apply to the areas referred to in Articles 73 and 74; 15) transfer of land, natural resources and public goods production and other forms of public economy; 16) the prevention of abuse of economic power; 17) promotion of agriculture and forestry, food security, import and export of agricultural products, outdoor and offshore fishing, coastal protection; 18) land traffic, land law, rent of agricultural goods, housing policy, settlement and allocation of family property for special categories of population; 19) measures against community

51 These areas are listed by the following points: 4) the place of residence and the right of establishment of aliens; 7) social welfare, 11) Economy-mining, industry, energy, trade , 13) science; 15) transfer of land, natural resources and publicly owned production facilities, 19a) healthcare; 20) food area; 22) road traffic; 25) and responsibility of the state 
and community illnesses, medical and other occupational health and therapeutic activities, medicines, medicines, anaesthetics and poisons; 20) the protection of life-giving products and stimulating means, objects for everyday use, fodder, seed and seedlings in agriculture and forestry, protection of plant diseases and pests and animal protection; 21) long and coastal navigation and maritime signs, river and lake navigation, meteorological services, sea routes, river and lake waterways intended for public transport; 22) road traffic and traffic by motor vehicles, construction and maintenance of roads for interurban and interstate traffic and collection and distribution of road use fees; 23) rail vehicles, not belonging to the Federal Railways, except for mountain railways; 24) waste removal, combating air pollution and combating noise; 25$)$ responsibility of the state; 26) medical assisted fertilization of human life, study and artificial alteration of genetic information as well as rules for transplantation of organs, tissues and cells; 27) the status and duties of officials of provinces, municipalities and other state bodies as well as judges in countries with the exception of career, wages and salaries; 28) hunting; 29) conservation of nature and landscaping; 30) land allocation; 31) planning; 32) water resources and 33) education and academic degrees.

Competing competence is such a competence that can be regulated normatively by the Federation and federal units, but not by both categories simultaneously. This means that in the Federal Republic of Germany federal units are allowed to adopt certain regulations, until the Federation decides to adopt uniform standards for the whole country.

Pursuant to Article 30 of the Federal Constitution, the states have exclusive competence in all affairs that are not assigned to the Federation. State affairs, with application of the principle of subsidiarity, are considered to be all affairs that directly meet the needs of the population of the state.

The relationship of the Federal Republic of Germany with the EU is regulated by the Federal Constitution, which stipulates that Germany is committed to the creation of a united Europe based on democratic, social and federal principles, the rule of law, and is aimed at protecting the principle of subsidiarity and the protection of fundamental human rights. Article 23 of the Federal Constitution regulates the relationship of the Federation to the EU with regard to the implementation of the principle of subsidiarity. In this connection, the Bundestag and the German countries, through the Bundesrat, are involved in solving EU issues. Regarding EU-related issues, the federal government is responsible for regularly informing the Bundestag and the Bundesrat.

Federal Constitutional Court of the Federal Republic of Germany decides on: 
- disputes relating to the rights and obligations of the Federation and states, particularly in the enforcement of federal laws by the states and on the conduct of federal oversight;

- in other disputes involving public law between the Federation and the states and between the states or within the states (Article 93, paragraph 1, points 3 and 4 of the Federal Constitution).

In the jubilee edition of the Selected Decisions of the German Federal Constitutional Court, federal disputes between the Federation and the states as well as between individual countries are marked as the first group of powers of the Federal Constitutional Court, within six groups of jurisdiction. ${ }^{52}$ In federal disputes, it is actually about disputes between the Federation and the states (Article 93 paragraph 1, point 3 of the Federal Constitution) and mutual disputes between the states (Article 93 paragraph 1, points 4 and 2 of the Federal Constitution). Mutual disputes between the states also enter into the scope of federal disputes, as all German states also have their own constitutional courts that settle mutual disputes. In this case, the subsidiarity of the suitability of the Federal Constitutional Court is only to be considered if the jurisdiction of the terrestrial constitutional courts is excluded due to the authorized initiators of the proceedings.

An example of the dispute between the Federal State and the states is the Decision of the German Federal Constitutional Court, dated 30 July 1958, which declared the invalidity of the Hamburg and Bremen Law on Referendums on the Use and Storing Nuclear Weapons. The Court explained its decision as authorizing the federal government to exclusively regulate certain issues, so a referendum on nuclear should be seen as an addition to the federal defence policy and belongs to the exclusive competence of the Federation ${ }^{53}$.

\subsection{Vertical division of competence in Switzerland}

The authority in Switzerland, in accordance with the Third Title of the Federal Constitution of Switzerland ${ }^{54}$ is structured on three territorial-political levels: Federal state (Bund), cantons and municipalities.

The federal constitution has divided the competence between the Federal State and cantons as follows:

\footnotetext{
52 Schwabe, J., Izabrane odluke njemačkog Saveznog Ustavnog suda, Jubilarno izdanje, p. 40-41, [http:// www.kas.de/wf/doc/kas_18056-1522-19-30.pdf?100517140444] Accessed 10.03.2019

53 Das Bundesverfassungsgericht BVerfGE 8, 104

54 Federal Constitution of the Swiss Confederation, of 18 April 1999 (Status as of $7^{\text {th }}$ March 2010)
} 
- the Federal State carries out the competences assigned to it by the Constitution (Article 42),

- all other competences not assigned to the Federal State are in the competence of the cantons, and cantons determine which affairs are within their competence (Article 43). This means that the competence of the Federal State is determined by the Federal Constitution, while all other competences under the general clause method belong to the cantons. The Federal State mainly has competences in the area of foreign policy, defences, monetary and foreign exchange system, customs, while the cantons are competent for education, culture, development, etc.

There is a relatively small number of exclusive competences of the first of the second of government, they are mostly divided, whereby the Federal State takes on those affairs that require uniform regulation and the cantons supplement their acts with the provisions of federal acts.

As part of the debate on the European Convention, particular issues were discussed concerning the division of powers between the European Union and its Member States, with an example of Switzerland in the working document for the European Parliament. The document noted that Switzerland offers an interesting variant: the list of exclusive competences is rather short, and the Swiss constitutional system places an emphasis on competing competences. The Swiss system of federal jurisdiction includes competences that are limited to principles, related competences without restriction and powers that allow parallel cantonal competencies ${ }^{55}$.

In 2014, the Federal Council presented the Report on Compliance with the NFA Principles (Subsidiarity, Fiscal Equivalence and Respect for Cantonal Organizational and Financial Autonomy $)^{56}$. In this way, the Federal Council is tasked with systematically analysing all tasks in which responsibility and / or funding belongs to the federal state and cantons, and the cantons actively contribute to their ideas in preparing this report. Financial equalization and division of tasks between the Federation and cantons (German: Neugestaltung des Finanzausgleichs und der Aufgabenteilung zwischen Bund und Kantonen - NFA) is regulated by four-year program agreements. Cantons allocate funds allocated to them by the Federal Government.

\footnotetext{
55 Lehmann, op.cit., note 2, p. IV

56 Bericht des Bundesrates vom 12. September 2014 über die Einhaltung der Grundsätze der NFA
} 
The principle of subsidiarity, in Switzerland, protects the canton's jurisdiction from usurpation by the central authorities. In accordance with Article 5 of the Swiss Constitution it is stipulated that "in the allocation and affairs of state functions, the subsidiarity principle must be respected“. According to the Swiss Constitution, the cantons are the dominant political actors, and they have a significant autonomy. The constitutional balance of the Swiss federal state is achieved through the principle of subsidiarity. The Swiss constitutional system is based on loyalty to the idea that power should be transferred in the greatest possible extent and that, unless otherwise defined, all authority remains in the cantons. In accordance with the principle of subsidiarity, the federal state can intervene only in the event of the impossibility of achieving a specific objective of the Swiss cantons. The intervention is not justified by the fact that the lower level is helpless, but whether the federal state can properly achieve the same goal. Moreover, in such cases, it is necessary to wait and see if cantons can on their own reach what they need.

Historically, the Federal Supreme Court of Switzerland was largely responsible for the application of federal law in the cantons. The Federal Supreme Court of Switzerland as the highest judicial authority, pursuant to Article 189 (2) of the Federal Constitution of Switzerland decides on disputes between the federal government and the canton or between the cantons.

Regarding the conflict between the Federation and cantons, in the jurisprudence of the Federal Supreme Court, it is important to remember:

- recognition of the superiority of federal laws over cantonal laws ${ }^{57}$ and

- appointment of voting rights to women in Appenzell Innerrhoden canton, contrary to the provisions of the cantonal $\operatorname{law}^{58}$.

Here we can also use the case of the Geneva canton dispute against the Federal Government regarding security issues. Geneva canton has filed a lawsuit against the Federal Government, claiming that it has violated its constitutional powers. The Federal Supreme Court has decided that it is natural for a federal government to be responsible for external and internal security. The Court therefore concluded that the Federal Government has inherent jurisdiction in the area of internal and external security, which excludes the remaining jurisdiction of the cantons in this area. However, cantons, due to their sovereignty, have an obligation to ensure security in their territory, given the parallel jurisdiction in police affairs ${ }^{59}$. This court decision influenced the amendment of Article 57 of the 1999 Constitution, which

BGE 127 I 60 E

58 BGE 116 Ia 359

59 Judgement of the Supreme Federal Court of 29 May 1991; ATF, 117 Ia 221, 228 
stipulates that the federal government and the cantons, within their jurisdictions, ensure the security of the country and its population. In addition, cantons must coordinate their efforts in the area of internal security.

\section{CONCLUSION}

Competence, above all, is a legal term because it determines the ability of a valid action, given the legal order of the EU, i.e. a specific state. The way of dealing with the legislation is inextricably linked with the question of competence. This narrows the level of freedom of government, but achieves a greater legal certainty, i.e. limitation of power. Finally, the existence of pre-established competences raises the legal certainty of citizens at a higher level and allows them contact with different levels of government.

The vertical division of competencies presupposes a clearer separation of responsibilities between different levels of government and a clear definition of their funding. Clear responsibilities bring greater efficiency and transparency in the fulfilment of responsibilities between levels of government.

The vertical distribution of competences between the EU and the Member States under the provisions of the Lisbon Treaty shows that a number of competences and responsibilities are shared between different levels of management within the EU. In this context, two principles emerge: equal legitimacy and responsibility of all levels of management, within their powers and the principle of fair cooperation. This results in the need for partnership work, which means that no level can directly answer on its own to the needs and challenges that the EU faces.

Based on the analysis of the delimitation of competences between the European Union and the Member States, it is evident from the Lisbon Treaty that Member States continue to retain a large number of competences. Of particular importance for the Member States is a provision of the EU which constitutes a general clause, according to which the competences not provided to the Union by the Treaties are retained by the Member States.

After almost ten years from the entry into force of the Lisbon Treaty, the division of competences between the EU and the Member States has resulted in a clearer, more coherent and better EU system.

The hypothesis set out in the introduction is confirmed as valid, because the federal states (Federal Republic of Germany and Switzerland) are the most similar to the pattern of competence distribution within the EU. They mark the model of guaranteed constitutional distribution of competences between the federal states 
and federal units, and there is no hierarchy between the political communities (the relationship of superiority and subordinations). As far as the position of local self-government is concerned, it is primarily governed by a regulation adopted by the federal unit. It is about equality of all levels of government and there is no place for a more powerful autonomous status of local units in relation to the federal state and federal units. This assumes non-centralization and a significantly higher level of cooperation between the levels of government. Within all three analysed models of vertical distribution of competencies (EU, Federal Republic of Germany and Switzerland) it is possible to see how the limitation of authority comes to the fore as one of the most important constitutional functions. From this it can be concluded that the principle of the limitation of authority is not applied only on the horizontal, but also on the actual and the vertical level. This results in a vertical delimitation of jurisdiction by area, i.e. limiting management from a single centre, which would rule over narrower levels of territorial authority. Vertical division of power implies the establishment of more authorities, among which competencies are divided and vary according to their content, scope and quality. In the vertical division of authority, the level of territorial authority, within the territorial political system, operates in accordance with its limited powers under a certain constitution. All three models are dominated by shared competencies between different levels of government.

In particular, it is possible to perceive the similarities between the EU, Germany and Switzerland in the general clause, which is on the side of affairs of narrower territorial units (EU Member States, German federal states and Swiss cantons). In general, the exclusive powers of the federal states usually include: foreign affairs, armed forces, means of communication and transport, monetary policy, customs and the federal judiciary. All affairs that are not assigned to the central government belong to the narrower units. The general clause defines competences in the basic acts:

- TEU (Article 5, paragraph 2, second sentence),

- The Basic Act of the Federal Republic of Germany (Article 30),

- Federal Constitution of Switzerland (Article 43).

In addition, all three basic acts contain the legal basis for applying the principle of subsidiarity:

- TEU (Article 5, paragraph 3),

- Basic Act of the Federal Republic of Germany (Article 23),

- Federal Constitution of Switzerland (Article 5). According to the principle of subsidiarity, public authorities must be entrusted to those authorities closest to citizens and that can perform efficiently and economically. 


\section{REFERENCES}

\section{BOOKS AND ARTICLES}

1. Bačić, A., Politička gramatika federalizma i hrvatsko povijesno iskustvo, Zbornik radova Pravnog fakulteta u Splitu, Vol. 44, Np. 2, 2007, p. 161-175

2. Bačić; A., Ustavno pravo i političke institucije, Pravni fakultet u Splitu, 2012

3. Bačić; A., Ustavno pravo Republike Hrvatske, Praktikum, Pravni fakultet Sveučilišta u Splitu, 2010

4. Benz, A.; Zimmer, C., The EU's competences: The 'vertical'perspective on the multilevel system, Living Reviews in European Governance, Vol. 5, No. 1, 2010 p. 1-30

5. Börzel, T. A.; Hosli, M. O., Brussels between Bern and Berlin: Comparative Federalism Meets the European Union, Governance, Vol. 16, No. 2, 2003, p. 179-202

6. Craig, P., The Lisbon Treaty Law, Politics and Treaty Reform, Oxford University Press, 2010, p. $159-161$

7. Craig, P.; De Búrca G., EU Law, Oxford University Press, Oxford, 2011

8. Craig, P.; De Búrca, G., The evolution of EU law, Oxford, Oxford University Press, 2nd edition 2011

9. Ćapeta, T.; Rodin, S., Osnove prava Europske unije, II. izmijenjeno i dopunjeno izdanje, Narodne novine d.d., Zagreb, 2011

10. Ćapeta, T., Sudska zaštita u Europskoj uniji nakon Lisabonskog ugovora, u Reforma Europske Unije-Lisabonski ugovor, Narodne novine, Zagreb, 2009, p. 89-118

11. Foster, N., Eu Law Directions, Oxford University Press, Oxford, 2016

12. Garben, S.; Govaere, I., The division of competences between the EU and its member states, Oxford: Hart Publishing, 2017

13. Hartley, T., Temelji prava Europske zajednice: uvod u ustavno i upravno pravo Europske zajednice, 2. hrv. izd. Rijeka, Pravni fakultet Sveučilišta, 2004

14. Hoffmeister, F., Litigating against the European Union and Its Member States - Who Responds under the ILC's Draft Articles on International Responsibility of International Organizations?, The European Journal of International Law, Vol. 21, No. 3, (C) EJIL 2010, p. 723-747

15. Itzcovich, G., The European Court of Justice as a Constitutional Court. Legal Reasoning in a Comparative Perspective, SANT'ANNA LEGAL STUDIES, STALS RESEARCH PAPER Vol. 4, 2014, p. 1-53

16. Lauc Z.: Odgovornost lokalne demokracije, u Ustavna demokracija i odgovornost, Okrugli stol održan 22. studenoga 2012. u palači Akademije u Zagrebu, Knjiga 19, Hrvatska akademija znanosti i umjetnosti, Znanstveno vijeće za državnu upravu, pravosuđe i vladavinu prava, Zagreb, 2013, p. 103.-110.

17. Lauc, Z., Temeljni pojmovi lokalne samouprave, Lokalna samouprava: hrvatska i nizozemska iskustva, Hrvatski institut za lokalnu samoupravu Osijek i Interkerklijk Vredesberad Haag, Osijek, 2001

18. Neumann F., Demokratska i autoritarna država, Zagreb, Naprijed, 1974 
19. Perišin, T., Razgraničenje ovlasti Europske unije i država članica, u Reforma Europske UnijeLisabonski ugovor, Narodne novine, Zagreb, 2009

20. Perišin, T., Ima li Europska unija ovlast regulirati privatno (posebice ugovorno) pravo?, Zbornik Pravnog fakulteta Zagreb Vol. 62, No. 5-6, 2012, p. 1799-1822

21. Portues, A., The principle of subsidiarity as a principle of economic efficiency, Columbia Journal of European Law, Vol. 17, 2012, p. 231-262

22. Rodin, M., Temeljna načela koja određuju odnos prava Europske unije i prava država članica, Hrvatska pravna revija, 2012, p. 1-14

23. Schütze, R., From Rome to Lisbon : 'Executive federalism' in the (new) European Union, Common market law review., Vol. 47, No, 5, 2010, pp. 1385-1427

24. Smerdel, B. (ed.), Primjena federalnog načela i pouke ustavne reforme 1971., Pravni fakultet Sveučilišta u Zagrebu i Centar za demokraciju i pravo Miko Tripalo, Zagreb, 2007

25. Smerdel, B., Ustavno uredenje europske Hrvatske, Narodne novine, Zagreb, 2013

26. Steiner, J.; Woods, L., EU Law, 11 th ed. Oxford University Press, Oxford, 2012, p. 56-57

27. Van Cleynenbreugel, P., Sharing powers within exclusive competences: Rethinking EU Antitrust Law Enforcement, CYELP, Vol. 12, 2016, p. 49-79

28. Vrban, D., Država i pravo, Golden marketing, Zagreb, 2003

\section{EU LAW}

1. Consolidated versions of the Treaty on European Union and the Treaty on the Functioning of the European Union, Official Journal of the European Union, C 202, Volume 59, 07.06. 2016.

2. Treaty of Lisbon amending the Treaty on European Union and the Treaty establishing the European Community, signed at Lisbon, 13 December 2007, Official Journal C 306 of 17 December 2007

3. Declaration on Article 352 of the Treaty on the Functioning of the European Union, Official Journal of the European Union, C 202, Volume 59, 07.06. 2016

4. White Paper on European Governance Commission of the European Communities, COM (2001) 428, Brussels, 25.7.2001

\section{COURT OF JUSTICE OF THE EUROPEAN UNION}

1. Cases 3, 4, and 6/76 Kramer (n 11 above) [30]-[33]

2. Case C-376/98 Germany v Parliament and Council (Tobacco Advertising I) [2000]

3. Case C-233/94 Germany v Parliament and Council [1997] ECR I-2405

4. Case C-547/14 Philip Morris, EU C: 2016: 325

5. Case C-288/12 European Commission v Hungary [2014]

6. Case C-643/15 and Case C-647/15 Slovak Republic and Hungary v Council of the European Union [2017]

7. Case C-358/14 Republic of Poland v. European Parliament, Council of the European Union [2016] 


\section{LIST OF NATIONAL REGULATIONS, ACTS AND COURT DECISIONS}

1. Grundgesetz für die Bundesrepublik Deutschland, 23.05.1949

2. Federal Constitution of the Swiss Confederation, of 18 April 1999 (Status as of 7 th March 2010)

3. BGE 127 I $60 \mathrm{E}$

4. BGE 116 Ia 359

5. BVerfGE 123, 267-Lisbon Decision (Lissabon-Urteil)

6. Judgement of the Supreme Federal Court of 29 May 1991; ATF, 117 Ia 221, 228

\section{REPORTS}

1. Bericht des Bundesrates vom 12. September 2014 über die Einhaltung der Grundsätze der NFA

2. Lehmann. W., Attribution of Powers and Dispute Resolution in Selected Federal Systems, Working Paper, European parliament, 2002

\section{WEBSITE REFERENCES}

1. Schwabe, J., Izabrane odluke njemačkog Saveznog Ustavnog suda, Jubilarno izdanje, p. 40-41, [http://www.kas.de/wf/doc/kas_18056-1522-19-30.pdf?100517140444] 10.03.2019

2. Omejec, J., Veliki njemački ustav i nepromjenjiva ustavna načela u praksi Saveznog ustavnog suda, 2016, [https://bib.irb.hr/datoteka/792156.OMEJEC_-_GRUNDGESETZ_-_Zbornik_PRAVO_I_PRAVDA_2015_PFBgd.pdf] Accessed 09.032019

3. The role of the "Flexibility clause“: Article 352, [https://ec.europa.eu/commission/sites/betapolitical/files/role-flexibility-clause_en.pdf] Accessed 03.05.2019 